\title{
PENGGUNAAN MEDIA KULTUR HASIL FERMENTASI DENGAN BAHAN YANG BERBEDA TERHADAP KANDUNGAN PROTEIN CACING SUTERA (Limnodrilus sp.)
}

\section{Use Of Fermentation Culture Media With Different Ingredients Against The Content Of Protein Tubifex Worm (Limnodrilus Sp.)}

\author{
Kurniati Lestari ${ }^{1}$, Slamet Riyadi $^{2}$, Supriyadi $^{3}$ \\ ${ }^{1}$ Dinas Pertanian dan Ketahanan Pangan Kota Palembang \\ ${ }^{2} \mathrm{cc}$ \\ ${ }^{3}$ Pemerhati Perikanan Palembang
}

*Corresponding author : kurniatilestari19@gmail.com

\begin{abstract}
ABSTRAK
Bahan organik yang menjadi substrat hidup dan sumber makanan bagi Cacing Sutera dapat ditingkatkan nutrisinya melalui kegiatan fermentasi. Oleh karena itu, perlu dilakukan penelitian terhadap Penggunaan Media Kultur Hasil Fermentasi. Penelitian ini menggunakan Rancangan Acak Lengkap (RAL) dengan 4 (empat) taraf perlakuan, masing-masing perlakuan dilakukan 3 (tiga) kali ulangan, yaitu $\mathrm{MK}_{0}$ (Debu batu bata $9 \mathrm{~kg}+$ fermentasi 4,5 kg kotoran kambing), $\mathrm{MK}_{1}$ (Debu batu bata $9 \mathrm{~kg}+$ fermentasi 4,5 $\mathrm{kg}$ kotoran kambing + fermentasi 2,25 kg ampas tahu) $\mathrm{MK}_{2}$ (Debu batu bata $9 \mathrm{~kg}+$ fermentasi 4,5 kg kotoran kambing + fermentasi 2,25 kg Azolla pinnata), $\mathrm{MK}_{3}$ (Debu Batu Bata $9 \mathrm{~kg}+$ Fermentasi 4,5 kg Kotoran Kambing + Fermentasi 2,25 kg Ampas Kelapa). Wadah yang digunakan berupa kotak kayu berbentuk melingkar berukuran $(60 \times 60 \times 20) \mathrm{cm}^{3}$ yang dilapisi plastik hitam. Media Pupuk yang digunakan difermentasi menggunakan $\mathbf{M A}_{11}$. Hasil penelitian menunjukkan bahwa perbedaan media budidaya yang berupa debu batu bata $9 \mathrm{~kg}+$ fermentasi $4,5 \mathrm{~kg}$ kotoran kambing + fermentasi $2,25 \mathrm{~kg}$ Azolla pinnata memberikan pengaruh $(\mathrm{p}<0,05)$ terhadap peningkatan kandungan protein Cacing Sutera sebesar $61,4 \%$.
\end{abstract}

Kata kunci : Cacing Sutera, Fermentasi, Media Bahan Organik

\begin{abstract}
Organic material which becomes a living substrate and a source of food for Tubifex worms can be increased nutrition through fermentation activities. Therefore, it is necessary to conduct research on the use of fermented culture media. This study used a completely randomized design (CRD) with 4 (four) levels of treatment, each treatment was carried out 3 (three) times, namely MKO (9 kg brick dust $+4.5 \mathrm{~kg}$ of goat manure), MK1 (dust $9 \mathrm{~kg}$ of bricks $+4.5 \mathrm{~kg}$ of goat manure + fermentation of $2.25 \mathrm{~kg}$ of tofu dregs) MK2 (9 $\mathrm{kg}$ of brick dust $+4.5 \mathrm{~kg}$ of goat manure + fermentation of $2.25 \mathrm{~kg}$ of Azolla pinnata), MK3 (Stone Dust $9 \mathrm{~kg}$ brick $+4.5 \mathrm{~kg}$ of goat manure fermentation $+2.25 \mathrm{~kg}$ coconut dregs fermentation). The container used is a circular wooden box measuring (60x60x20) cm3 covered with black plastic. The fertilizer media used is fermented using MA11. The results showed that the difference in cultivation media in the form of $9 \mathrm{~kg}$ brick dust $+4.5 \mathrm{~kg}$ of goat manure fermentation $+2.25 \mathrm{~kg}$ fermentation of Azolla pinnata had an effect $(p<0.05)$ on the increase in the protein content of tubifex worms by $61.4 \%$.
\end{abstract}

Keywords: Tubifex Worms, Fermentation, Organic Material Media 


\section{PENDAHULUAN}

Cacing Sutera (Limnodrilus sp) merupakan salah satu jenis pakan alami yang mempunyai peranan penting dalam memacu pertumbuhan ikan (Sumaryam, 2000 dalam Pursetyo dkk., 2011). Kegiatan usaha budidaya Cacing Sutera maupun kegiatan penangkapan Cacing Sutera di alam saat ini belum memperhatikan kualitas nutrisi Cacing Sutera, terutama kandungan protein. Menurut Chumaedi dkk. (1992), habitat atau tempat hidup pada Cacing Sutera yang berupa bahan organik terlarut merupakan sumber makanan bagi Cacing Sutera dan merupakan faktor yang mempengaruhi produksi dan kualitas Cacing Sutera. Bahan-bahan organik yang pernah digunakan antara lain : media lumpur halus dengan kombinasi penambahan pupuk kotoran ayam, dedak halus dan ampas tahu (Suharyadi, 2012) dan media lumpur dengan kombinasi kotoran sapi dan limbah lumpur kelapa sawit fermentasi (Jaohari, 2012).

Suharyadi (2012), melaporkan bahwa budidaya Cacing Sutera dengan media lumpur halus dengan penambahan bahan organik yang berbeda selama 21 hari yaitu; kotoran ayam menghasilkan protein $14,31 \%$, dedak halus menghasilkan protein $15,94 \%$ dan ampas tahu menghasilkan protein $14,42 \%$. Menurut Jaohari (2012), penggunaan kombinasi media lumpur dengan penambahan bahan organik kotoran sapi dan limbah lumpur kelapa sawit yang difermentasi menghasilkan protein $22,11 \%$ pada hari ke 30 dan menghasilkan protein 25,24\% pada hari ke 60 .

Ampas kelapa merupakan limbah industri atau limbah rumah tangga yang sangat potensial untuk dimanfaatkan sebagai sebagai bahan organik pada media Cacing Sutera. Ampas kelapa hasil sampingan dari pembuatan santan dan minyak kelapa masih memiliki kandungan protein yang cukup tinggi yaitu 18,2\% (Putri, 2010). Azolla (Azolla pinnata) adalah tumbuhan mempunyai keistimewaan mampu mengikat $\mathrm{N}$ bebas dari udara karena bersimbiosis dengan ganggang biru (Anabaena azolae), sehingga mengandung protein yang cukup tinggi. Azolla memiliki kandungan protein kasar 24-30 \% (Abdulkadir, 1989). Ampas tahu merupakan sisa hasil pembuatan tahu yang memiliki kandungan gizi yang cukup baik dengan protein kasar sekitar 20,26\% (Mahfudz,dkk., 2001). Oleh karena itu ampas kelapa, Azolla dan ampas tahu cukup potensial sebagai sumber budidaya Cacing Sutera.

Sehubungan dengan hal tersebut penulis bermaksud mengetahui kandungan protein melalui penelitian dengan menggunakan bahan organik yang berasal dari kotoran kambing, ampas kelapa, Azolla, dan ampas tahu yang difermentasi sebagai media budidaya Cacing Sutera (Limnodrilus sp). Tujuan penelitian ini adalah Untuk mengetahui nilai kandungan protein pada bahan organik sebelum dan setelah difermentasi menggunakan probiotik MA-11 yang digunakan sebagai media kultur Cacing Sutera, mengetahui pertambahan nilai kandungan protein Cacing Sutera yang terbaik pada media kultur Cacing Sutera yang berbeda.

\section{METODE PENELITIAN Waktu dan Tempat}

Kegiatan penelitian ini dilaksanakan selama 40 hari dimulai pada Agustus sampai September bertempat di Jln Sukabangun II Gang Langgar RT 08 RW 02 No 2406 Kecamatan Sukarami, Palembang.

\section{Metode Penelitian}

Penelitian ini menggunakan metode percobaan pola Rancangan Acak Lengkap (RAL) yang terdiri dari 4 perlakuan dan 3 ulangan. Pada penelitian ini sebagai perlakuan adalah media yang digunakan yaitu: 
MK0: Debu Batu Bata $9 \mathrm{~kg}+$ Fermentasi Kotoran Kambing $4,5 \mathrm{~kg}$

MK1: Debu Batu Bata $9 \mathrm{~kg}+$ Fermentasi Kotoran Kambing $4,5 \mathrm{~kg}+$ Fermentasi Ampas Tahu 2,25 kg

MK2: Debu Batu Bata $9 \mathrm{~kg} \quad+$ Fermentasi Kotoran Kambing $4,5 \mathrm{~kg}+$ Fermentasi Azolla pinnata $2,25 \mathrm{~kg}$

MK3: Debu Batu Bata $9 \mathrm{~kg}+$ Fermentasi Kotoran Kambing $4,5 \mathrm{~kg}+$ Fermentasi Ampas Kelapa 2,25 kg

\section{Prosedur Kerja \\ Persiapan Wadah}

Wadah yang digunakan berupa kotak papan yang didesain menjadi bentuk melingkar sebanyak 12 buah dengan ukuran panjang $60 \mathrm{~cm}$, lebar $60 \mathrm{~cm}$, dan tinggi $20 \mathrm{~cm}$. Luas masing-masing wadah $0,36 \mathrm{~m}^{2}$ dan ketebalan papan $2 \mathrm{~cm}$. Bagian dalam kotak papan dilapisi lembaran plastik untuk mencegah kebocoran. Desain wadah yang digunakan dalam penelitian dapat dilihat pada Lampiran 2.

\section{Persiapan Media}

Persiapan media (Debu Batu Bata, Kotoran Kambing, Ampas Tahu, Azolla, Ampas Kelapa) untuk budidaya Cacing Sutera meliputi : persiapan bahan media, proses pengeringan media, proses fermentasi media dan pencampuran media Cacing Sutera. Debu batu bata yang merupakan substrat dasar pemeliharaan Cacing Sutera diperoleh dari tempat pembuatan batu bata di Kelurahan Talang Jambe Kecamatan Sukarame Palembang. Debu batu bata yang dibutuhkan sebanyak $108 \mathrm{~kg}$ dalam bentuk debu yang halus.

Kotoran kambing sebagai sumber bahan organik pada budidaya Cacing Sutera diperoleh dari kandang peternak kambing di Kelurahan Talang Jambe Kecamatan Sukarame Palembang.
Kotoran kambing yang dibutuhkan sebanyak $54 \mathrm{~kg}$. Proses persiapan bahan media kotoran kambing terdiri dari penghalusan bahan media dan fermentasi bahan media.

Kotoran kambing yang diperoleh telah kering sehingga tidak perlu dilakukan proses pengeringan, tetapi dilakukan proses penghalusan dan pengayakan karena masih terdapat kotoran kambing yang berbentuk bulat. Selanjutnya, tepung kotoran kambing difermentasi menggunakan larutan activator . larutan activator yang digunakan dibuat dengan cara mencampurkan 1 sendok gula merah, 44 cc Microbacter Alfaafa 11 (MA 11), dan 1,1 liter air bersih. Proses fermentasi dilakukan pada drum yang tertutup rapat selama 7 hari.

Ampas tahu merupakan tambahan bahan organik yang menjadi perlakuan dalam penelitian diperoleh dari pabrik pembuatan tahu di Jalan Bambang Utoyo Lorong Sianjur III Rt 02 Kelurahan 5 Ilir Kecamatan Ilir Timur II Palembang. Ampas tahu yang diperlukan sebanyak $6,75 \mathrm{~kg}$. proses persiapan media ampas tahu terdiri dari pengeringan bahan media dan fermentasi bahan media.

Proses pengeringan ampas tahu diawali dengan proses pengepresan untuk membuang air, kemudian dilakukan pengukusan selama 30 menit dengan suhu $80{ }^{\circ} \mathrm{C}$ dan dijemur kembali selama 2 hari. Selanjutnya, tepung ampas tahu difermentasi menggunakan larutan aktivator . larutan aktivator yang digunakan dibuat dengan cara mencampurkan 1/4 sendok gula merah, 6 cc Microbacter Alfaafa 11 (MA 11), dan 0,15 liter air bersih. Proses fermentasi dilakukan pada drum yang tertutup rapat selama 7 hari.

Azolla pinnata merupakan bahan organik yang menjadi perlakuan dalam penelitian diperoleh dari perairan rawa daerah Kayu Agung Kabupaten Ogan 
Komering Ilir. Azolla pinnata yang diperoleh dalam bentuk segar, sehingga perlu dilakukan proses pengeringan dengan cara dijemur di bawah sinar matahari selama 3-4 hari. Selanjutnya, tepung Azolla pinnata difermentasi menggunakan larutan aktivator . Larutan aktivator yang digunakan dibuat dengan cara mencampurkan $1 / 4$ sendok gula merah, 6 cc Microbacter Alfaafa 11 (MA 11), dan 0,15 liter air bersih. Proses fermentasi dilakukan pada drum yang tertutup rapat selama 7 hari.

Ampas kelapa merupakan tambahan bahan organik yang menjadi perlakuan dalam penelitian diperoleh dari pedagang santan kelapa di pasar tradisional KM 5 Palembang. Proses persiapan bahan media ampas kelapa terdiri dari proses pengeringan dan proses fermentasi. Ampas kelapa yang dibutuhkan sebanyak $6,75 \mathrm{~kg}$ dilakukan pengukusan selama 30 menit dengan suhu air $80{ }^{\circ} \mathrm{C}$. Setelah pengukusan, ampas kelapa didinginkan di atas plastik formika dan kemudian dijemur selama 3 jam. Selanjutnya, tepung ampas kelapa difermentasi menggunakan larutan aktivator. Larutan aktivator yang digunakan dibuat dengan cara mencampurkan 1/4 sendok gula merah, 6 cc Microbacter Alfaafa 11 (MA 11), dan 0,15 liter air bersih. Proses fermentasi dilakukan pada drum yang tertutup rapat selama 7 hari.

\section{Kultur Cacing Sutera}

Pembuatan Media Kultur Cacing Sutera

Media bahan organik yang telah difermentasi, diambil sampel sebanyak 500 gram setiap perlakuan untuk diuji kandungan $\mathrm{C} / \mathrm{N}$ Laboraturium Kimia, Biologi dan Kesuburan Tanah Jurusan Ilmu Tanah Fakultas Pertanian Unsri. Media bahan organik yang telah difermentasi dicampur dengan debu batu bata dengan perbandingan pupuk dan substart mengikuti penelitian Yuherman (1987) dalam Syam (2012), yaitu perbandingan 1
: 1. Campuran tersebut diaduk merata dan dibuat ketinggian $6 \mathrm{~cm}$. Selanjutnya, dilakukan pengisian air setinggi $2 \mathrm{~cm}$ di atas permukaan. Debit aliran air yang digunakan mengikuti penelitian Ismail (2013), yaitu $500 \mathrm{ml} / \mathrm{menit}$, debit air yang masuk kedalam wadah diatur dengan menggunakan klep pada selang pemasukan. Pengaliran air dilakukan dengan sistem resirkulasi air. Setelah diisi air, wadah dibiarkan selama 7 hari. Penggenangan ini bertujuan supaya bahan organik pada media dapat lebih cepat terurai.

\section{Penebaran Bibit Cacing Sutera}

Cacing Sutera yang akan dijadikan bibit, terlebih dahulu dianalisis kandungan proteinnya. Pengujian proximat protein ini dilakukan pada Balai Riset dan Standardisasi Industri Palembang.

Penebaran Cacing Sutera dilakukan setelah 7 hari penggenangan. Perlakuan pada penebaran ini diambil berdasarkan penelitian Ismail (2013), yang melakukan penebaran sebanyak 100 g/wadah, penebaran cacing Sutera dibagi menjadi 4 titik di setiap wadah perlakuan, yaitu 4 titik pada setiap sudut wadah. Masing-masing titik ditebar sebanyak 25 gram Cacing Sutera.

Cacing Sutera yang digunakan sebagai bibit didapat dari hasil tangkapan pengumpul Cacing Sutera pada kolam retensi di daerah Demang Lebar Daun. Sebelum dimasukan ke dalam wadah kultur, cacing ditimbang dengan cara memasukan cacing kedalam gelas plastik transparan dan setelah itu diaklimatisasi selama 5 menit. Aklimastisasi cacing dilakukan dengan cara menambahkan air dari wadah budidaya ke dalam gelas plastik yang berisi cacing sehingga air dari wadah dan di dalam gelas bercampur.

\section{Penambahan Bahan Organik}

Penambahan bahan organik yang diberikan adalah bahan organik yang telah 
difermentasi (kotoran kambing, Azolla, ampas kelapa, dan ampas tahu) menggunakan aktivator $\mathrm{MA}_{11}$ selama 7 hari. Pemberian bahan organik berdasarkan penelitian Syam (2012), dilakukan setiap 15 hari sekali. Dosis bahan organik yang diberikan berdasarkan penelitian (Fadilah, 2004 dalam Syam, 2012), yaitu sebanyak $1 \mathrm{~kg} / \mathrm{m}^{2}$. Bahan organik yang diberikan dengan cara ditebar secara merata setelah aliran air dihentikan terlebih dahulu. Setelah penebaran pupuk, 10 menit kemudian air dapat dialirkan kembali ke dalam wadah.

\section{Parameter Yang Diamati}

Parameter penelitian meliputi parameter utama dan parameter penunjang. Parameter utama meliputi : Pengujian kandungan protein cacing Sutera. Parameter penunjang meliputi: Pengujian kandungan $\mathrm{C} / \mathrm{N}$ bahan organik media kultur hasil fermentasi dan pengukuran kualitas air.

\section{Analisa data}

Analisis data dalam penelitian ini mengacu ke buku Teori dan Aplikasi Rancangan Percobaan (Hanafiah, 2005), Data hasil penelitian dianalisis secara statistika dengan menggunakan Analisis Sidik Ragam (ANSIRA).

\section{HASIL DAN PEMBAHASAN}

\section{Nilai Protein Cacing Sutera}

Hasil pengujian kandungan protein Lacing Sutera (Limrrodrilns sp) selama 40 hari pemeliharaan dari masing-masing perlakuan dapat dilihat pada gambar 1,2 dan 3.
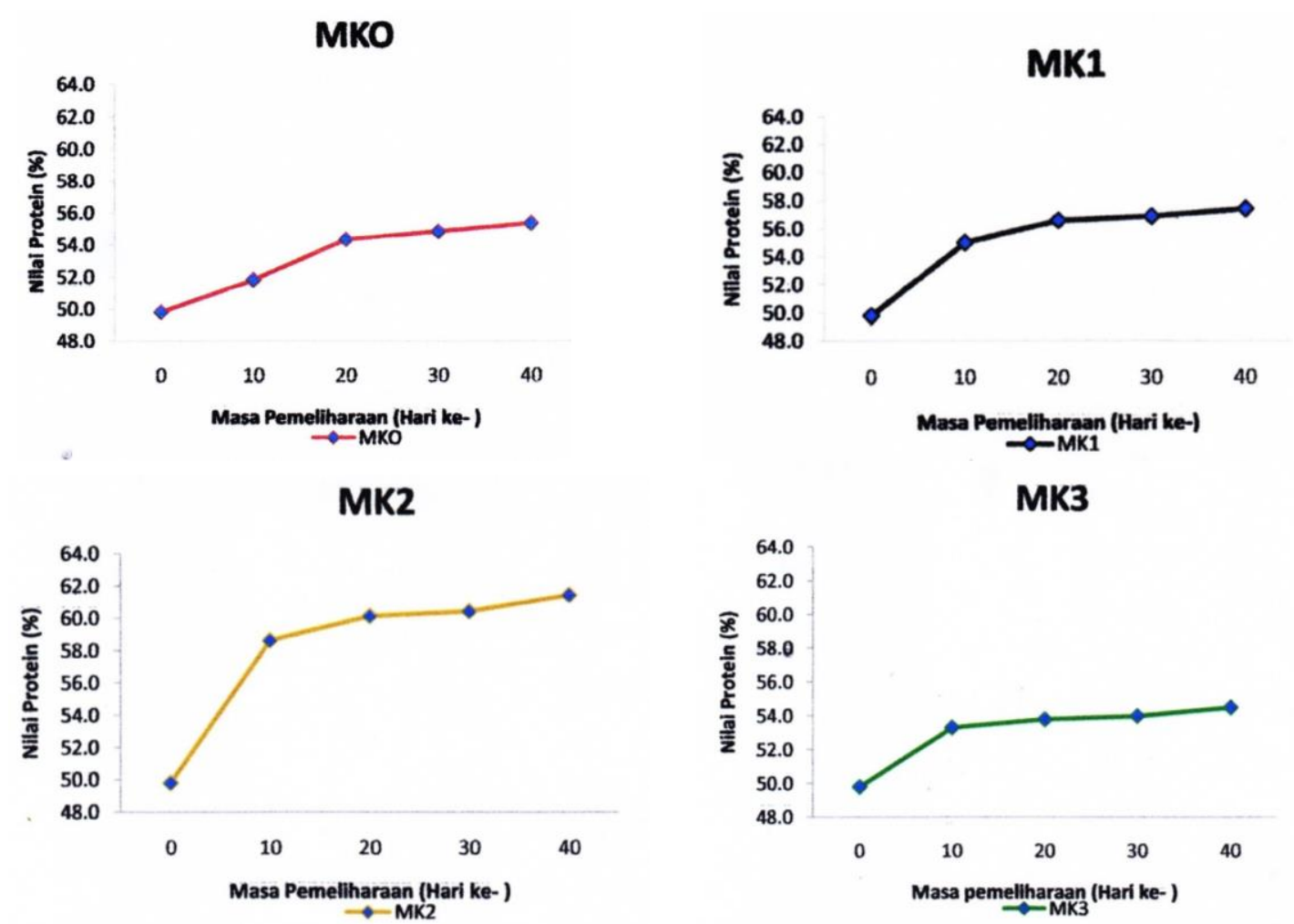

Gambar 1: Kandungan Protein cacing sutera pada masing-masing perlakuan MK0, MK1,MK2 dan MK3 yang dipelihara selama 40 hari.

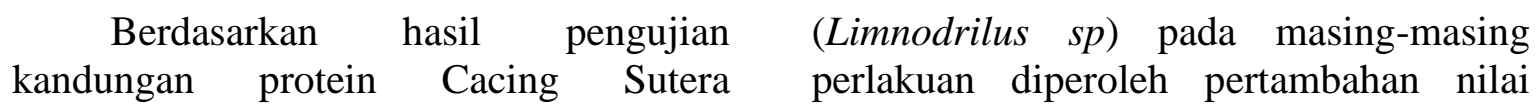


kandungan protein rata-rata yaitu pada perlakuan $\mathrm{MK}_{0}$ sebesar 5,5\% $\mathrm{MK}_{1}(7,6 \%)$, $\mathrm{MK}_{2}(11,6 \%)$ serta MK3 ( 4,7 \%). perlakuan $\mathrm{MK}_{2}$ memiliki nilai kandungan protein tertinggi pada hari ke 40 dibandingkan dengan perlakuan lainnya yaitu $61,4 \%$. Hal ini diduga karena media pada perlakuan $\mathrm{MK}_{2}$ berpengaruh dalam meningkatkan kandungan protein cacing sutera selama pemeliharaan karena memiliki kandungan protein yang tinggi dibandingkan media perlakuan yang lain. Selain itu, pada perlakuan $\mathrm{MK}_{2}$, tanaman Azolla pinnata juga memiliki asam-asam amino yang lengkap dan kandungan serat kasar yang tinggi sehingga protein yang ada pada bahan organik lebih terserap secara maksimal oleh cacing Sutera. Menurut Fadholi (2001) dalam Jaohari (2012), kandungan nutrisi cacing sutera dipengaruhi oleh makanan yang tersedia. Selanjutnya Chumaidi dkk., (1992) menyatakan bahwa bahan organik pada media pemeliharaan juga merupakan sumber makanan bagi Cacing Sutera.

Perhitungan analisis sidik ragarn kandungan protein Cacing Sutera (I,imnndrilars sp) dari masing-masing perlakuan dapat dilihat pada Tabel 1 . Selanjutnya, data pertambahan kandungan protein Cacing Sutera terdapat pada tabel 2:

Tabe1 1. Hasil Analisis Sidik Ragam Kandungan Protein Cacing Sutera

\begin{tabular}{lcccccc}
\hline SK & DB & JK & KT & FHitung & \multicolumn{2}{c}{ F $_{\text {Tabel }}$} \\
\hline Perlakuan & 3 & 87,87 & 29,29 & $79,34^{* *}$ & 4,04 & $\mathbf{0 , 0 1}$ \\
Galat & 8 & 2,95 & 0,37 & & & \\
Total & 11 & 90,82 & & & & \\
\hline
\end{tabular}

Keterangan : $=* *$ Berbeda Sangat Nyata

Tabel 2. Hasil Analisis Sidik Ragam Pertambahan Kandungan Protein Cacing Sutera

\begin{tabular}{lcccccc}
\hline SK & DB & JK & KT & FHitung & \multicolumn{2}{c}{ F $_{\text {Tabel }}$} \\
\hline Perlakuan & 3 & 84,0 & 28,0 & $79,40^{* *}$ & 2,306 & 3,355 \\
Galat & 8 & 2,8 & 0,4 & & & \\
Total & 11 & 86,8 & & & & \\
\hline
\end{tabular}

Keterangan : $=* *$ Berbeda Sangat Nyata

Dari hasil analisis keragaman pada tabel 1 dan tabel 2 menunjukkan perlakuan yang diteliti $\left(\mathrm{MK}_{0}, \mathrm{MK}_{1}, \mathrm{MK}_{2}\right.$ dan $\left.\mathrm{MK}_{3}\right)$ menunjukkan hasil yang berbeda sangat nyata. Nilai koefisien keragaman (KK) kandungan protein Cacing Sutera sebesar
$1,1 \%$, maka untuk uji lanjut digunakan uji BNJ (Tabel 3). Selanjutnya, Nilai Koefisien Keragaman (KK) pertambahan kandungan protein Cacing Sutera sebesar $8,1 \%$, maka untuk uji lanjut digunakan uji BNT (Tabel 4).

Tabel 3. Uji Lanjut BNJ Pengaruh Perlakuan Media Hasil Fermentasi yang Berbeda Terhadap Kandungan Protein Cacing Sutera (Limnodrilus sp)

\begin{tabular}{lcc}
\hline Perlakuan & Rerata & BNJo,01=1,97 \\
\hline MK $_{3}$ & 54,5 & $\mathrm{a}$ \\
$\mathrm{MK}_{0}$ & 55,0 & $\mathrm{a}$ \\
$\mathrm{MK}_{1}$ & 57,4 & $\mathrm{~b}$ \\
$\mathrm{MK}_{2}$ & 61,4 & $\mathrm{c}$
\end{tabular}

Keterangan : Huruf superscript yang berbeda pada kolom yang sama menunjukkan pengaruh perlakuan yang berbeda nyata (uji Ducan; $\mathrm{P}<0,05$ ). 
Tabe1 4. Uji Lanjut BNT Pengaruh Perlakuan Media Hasi1 Fermentasi yang Berbeda Terhadap Pertambahan Kandungan Protein Cacing Sutera (Limnodrilus sp)

\begin{tabular}{lcc}
\hline Perlakuan & Rerata & BNJ $_{\mathbf{0}, \mathbf{0 1}}=\mathbf{1 , 4 8}$ \\
\hline $\mathrm{MK}_{3}$ & 4,7 & $\mathrm{a}$ \\
$\mathrm{MK}_{0}$ & 5,5 & $\mathrm{~b}$ \\
$\mathrm{MK}_{1}$ & 7,6 & $\mathrm{c}$ \\
$\mathrm{MK}_{2}$ & 11,6 & $\mathrm{~d}$ \\
\hline
\end{tabular}

Keterangan : Huruf superscript yang berbeda pada kolom yang sama menunjukkan pengaruh perlakuan yang berbeda nyata (uji Ducan; $\mathrm{P}<0,05$ ).

Pada Tabel 3 hasil uji BNJ menunjukkan bahwa perlakuan media hasil fermentasi yang berbeda terhadap kandungan protein Cacing Sutera (Limnodrilus sp) pada perlakuan $\mathrm{MK}_{2}$ berbeda sangat nyata dengan perlakuan $\mathrm{MK}_{0}, \mathrm{MK}_{1}$ dan MK3. Perlakuan MK, berbeda sangat nyata dengan perlakuan $\mathrm{MK}_{0}$ dan $\mathrm{MK}_{3}$. Selanjutnya, perlakuan $\mathrm{MK}_{0}$ tidak berbeda nyata dengan perlakuan $\mathrm{MK}_{3}$. Pada perlakuan $\mathrm{MK}_{2}$ menunjukkan nilai kandungan protein tertinggi pada hari ke 40 dibandingkan dengan perlakuan lainnya yaitu $61,4 \%$.

Pada Tabel 4, hasil uji BNT menunjukkan bahwa perlakuan media hasil fermentasi yang berbeda terhadap pertambahan kandungan protein Cacing Sutera (Limnodrilussp) pada perlakuan $\mathrm{MK}_{2}$ berbeda sangat nyata dengan perlakuan $\mathrm{MK}_{0}, \mathrm{MK}_{1}$ dan $\mathrm{MK}_{3}$. Perlakuan MK, berbeda sangat nyata dengan perlakuan $\mathrm{MK}_{0}$ dan $\mathrm{MK}_{3}$. Selanjutnya, perlakuan $\mathrm{MK}_{0}$ berbeda sangat nyata dengan perlakuan $\mathrm{MK}_{3}$.

Pada perlakuan $\mathrm{MK}_{2}$ menunjukkan nilai pertambahan kandungan protein tertinggi dibandingkan dengan perlakuan lainnya yaitu $11,6 \%$. Hal ini diduga karena adanya penambahan bahan organik setiap 15 hari sekali pada setiap perlakuan dan nilai kandungan protein bahan organik tertinggi adalah pada perlakuan $\mathrm{MK}_{2}$ yang menggunakan bahan organik berupa Azolla pinnata. Menurut Efendi (2013), pemupukan perlu dilakukan agar media yang digunakan sebagai substrat cacing Sutera tetap subur. Berdasarkan hasil pengujian kandungan protein sebelum dan sesudah fermentasi serta kadar $\mathrm{C} / \mathrm{N}$ pada media yang pemeliharaan Cacing Sutera, kandungan protein pada bahan media setelah fermentasi meningkat. Hal ini disebabkan karena proses fermentasi menyederhanakan partikel bahan pakan sehingga akan meningkatkan nilai gizinya. Bahan pakan yang telah mengalami fermentasi akan lebih baik kualitasnya dari pada bahan bakunya (Suharyadi, 2012). Proses fermentasi menggunakan probiotik MA 11 (Microbacter Alfaafa 11) selama 7 hari. Pada probiotik MA 11 terdapat bakteri protiotik, selulotik dan amilolitik yang mampu merombak material organik dengan cara memecah dinding lignin yang menyelubungi kandungan gizi yang selama ini sulit dirombak.

\section{Kandungan Protein Bahan Organik}

Pada perlakuan $\mathrm{MK}_{0}, \mathrm{MK}_{1}, \mathrm{MK}_{2}$ dan $\mathrm{MK}_{3}$ sumber protein merupakan protein nabati. Pada semua bahan organik yang digunakan dalam perlakuan penelitian, terjadi peningkatan nilai kandungan protein setelah proses fermentasi. Hal ini diduga, pada saat proses fermentasi terjadi penyederhanaan partikel bahan pakan (protein) oleh aktifitas mikroba sehingga nilai kandungan protein meningkat dan lebih mudah diserap oleh tubuh cacing Sutera. Hal ini juga ditegaskan oleh Winedar et al., (2004), bahwa pada proses 
fermentasi terjadi penambahan unsur nitrogen dari sel mikroorganisme atau senyawa volatile yang lepas dan menyebabkan terjadinya perombakan unsur organik pakan, sehingga komponen dalam pakan menjadi lebih sederhana. Selanjutnya, Gaman dan Sherrington
(1992) dalam Winedar et al., (2004) menyatakan bahwa peningkatan kandungan protein disebabkan oleh terjadinya peningkatan unsur nitrogen yang terdapat pada bahan organik berkarbohidrat dalam bentuk garam ammonium atau nitrat.

Tabel 5. Uji Protein Media Bahan Organik Sebelum dan Setelah Fermentasi, serta Kadar C/N Setelah Fermentasi

\begin{tabular}{lccc}
\hline Bahan Organik & $\begin{array}{c}\text { Kandungan Protein } \\
\text { Sebelum Fermentasi }\end{array}$ & $\begin{array}{c}\text { Kandungan Protein } \\
\text { Setelah Fermentasi }\end{array}$ & C/N \\
\hline Kotoran Kambing & $8,7 \%$ & $10,9 \%$ & 13 \\
Ampas Tahu & $6,9 \%$ & $11,3 \%$ & 18 \\
Azolla pinata & $12,5 \%$ & $16,9 \%$ & 14 \\
Ampas Kelapa & $2,82 \%$ & $6,10 \%$ & 20 \\
\hline
\end{tabular}

Keterangan : Protein diuji pada Laboraturium Baristand Industri Palembang, kadar C/N diuji pada Laboraturium Kimia, Biologi dan Kesuburan Tanah Fakultas Pertanian LTNSRI

Nilai kandungan protein yang berbeda pada setiap komposisi bahan media pemeliharaan Cacing Sutera berpengaruh terhadap kandungan protein Cacing Sutera yang dipelihara selama 40 hari. Pada penelitian yang dilakukan Jaohari (2012), Cacing Sutera yang dipelihara menggunakan media kotoran sapi dan limbah lumpur kelapa sawit menghasilkan Cacing Sutera yang memiliki kandungan protein $22,11 \%$ pada hari ke 30 dan memiliki kandungan protein $25,24 \%$ pada hari ke 60. Selanjutnya Suharyadi (2012) melakukan penelitian terhadap penggunaan pupuk yang berbeda selama 20 hari menghasilkan Cacing Sutera yang memiliki kandungan protein 14,42\% (pemupukan dengan Ampas tahu), 14,31\% (pemupukan dengan Kotoran Ayam), dan $15,94 \%$ (pemupukan dengan dedak). Menurut Muchtadi (2010), protein yang terkandung dalam bahan pangan setelah dikonsumsi akan mengalami pencernaan (pemecahan atau hidrolisis oleh enzimenzim protease) menjadi unit-unit penyusunnya, yaitu asamasam amino yang selanjutnya diserap oleh tubuh melalui usus kecil yang kemudian dialirkan ke seluruh tubuh.
Nilai gizi protein merupakan kemampuan suatu protein untuk dapat dimanfaatkan oleh tubuh sebagi sumber nitrogen untuk sintesis protein tubuh. Faktor yang menentukan nilai gizi suatu protein adalah daya cerna dan kandungan asam amino esensial (Winarno, 1997). Mahfudz dkk, (2011) menyatakan bahwa ampas tahu memiliki kandungan serat kasar 20,26 \% dan menurut Arifbowo (2007), ampas tahu memiliki kandungan asam amino yang lengkap dan seimbang namun dalam jumlah yang kecil. Hal ini menunjukan bahwa ampas tahu memiliki nilai gizi protein dengan adanya kandungan serat kasar dan asam amino, sehingga kandungan protein yang terdapat pada ampas tahu dapat diserap oleh Cacing Sutera.

Ampas kelapa memiliki kandungan serat kasar 28,72 \% dan kandungan asam amino yang tidak lengkap (tidak terdapat lisin) (Hidayati, 2011). Hal ini diduga menyebabkan bahan media ampas kelapa memiliki daya cerna yang rendah karena kandungan serat kasarnya yang cukup tinggi sehingga kandungan protein yang terdapat pada ampas kelapa kurang bisa diserap secara keseluruhan oleh Cacing Sutera. 
Azolla pinata memiliki nilai gizi protein dengan kandungan serat kasar 23,06 \% dan memiliki komposisi asam amino yang lengkap (Handajani, 2006). Hat ini diduga, daya cerna pada Azolla pinnata cukup baik karena serat kasarnya yang cukup tinggi $(23,06 \%)$ mengakibatkan asam-asam amino yang terkandung pada Azolla pinata mudah diserap oleh cacing Sutera sehingga kandungan protein Cacing Sutera lebih meningkat dibandingkan bahan-bahan yang lain (Ampas Tahu dan Ampas Kelapa). Hal ini didukung oleh pernyataan Rustanto (2009) dalam Agustono $d k k$, (2010) bahwa proses fermentasi yang merombak protein dan mendegradasi serat kasar menyebabkan daya cema semakin baik sehingga bahan organik dapat digunakan secara optimal.

Rasio C/N dalam penelitian ini merupakan hasil analisis $\mathrm{C} / \mathrm{N}$ sesudah proses fermentasi. Rasio $\mathrm{C} / \mathrm{N}$ memiliki nilai $\mathrm{C} / \mathrm{N}$ antara 13-20 yang menandakan bahwa bahan organik tersebut sudah dapat digunakan sebagai media kultur cacing Sutera. Hal ini mengindikasikan bahwa bahan organik sudah terurai atau terdegradasi secara sempurna sehingga bisa diaplikasikan. Menurut Pancapalaga (2011) dalam Hidayati (2013), rasio C/N merupakan perbandingan antara karbon dan nitrogen. Jumlah rasio $\mathrm{C} / \mathrm{N}$ dapat digunakan sebagai indikator proses fermentasi yaitu jika jumlah perbandingan antara karbon dengan nitrogen masih berkisar 10 - 20 maka hal tersebut mengindikasikan bahwa bahan organic yang difermentasi sudah bisa untuk digunakan sebagai media kultur Cacing Sutera.

Rasio $\mathrm{C} / \mathrm{N}$ pada kotoran kambing, ampas tahu, Azolla pinnata dan ampas kelapa menunjukkan nilai bahan organik yang sudah siap digunakan sebagai media kultur Cacing Sutera dan menghasilkan nilai kandungan protein yang meningkat (Lampiran 20). Menurut Wikipedia (2014), Mikroba memecah senyawa $\mathrm{C}$ sebagai sumber energi dan menggunakan $\mathrm{N}$ untuk sintesis protein. Pada rasio C/N di antara $10 \mathrm{~s} / \mathrm{d} 20$ mikroba mendapatkan cukup $\mathrm{C}$ untuk energi dan $\mathrm{N}$ untuk sintesis protein. Apabila rasio $\mathrm{C} / \mathrm{N}$ terlalu tinggi, mikroba akan kekurangan $\mathrm{N}$ untuk sintesis protein sehingga dekomposisi berjalan lambat. Selanjutnya Avnimelech et al., (1994) dalam Rahman (2012) menyatakan bahwa C/N memberikan pengaruh pada pertambahan bakteri yang menjadi makanan bagi Cacing Sutera (Limnodrilus sp). Hubungan rasio $\mathrm{C} / \mathrm{N}$ dengan mekanisme kerja bakteri yaitu bakteri memperoleh makanan melalui susbtrat karbon dan nitrogen dengan perbandingan tertentu sehingga jumlah bakteri dapat meningkat. Kandungan $\mathrm{C} / \mathrm{N}$ pada bahan organik masing-masing media yang digunakansebagai media kultur Cacing Sutera berkisar antara 13-20, hal ini menyebabkan penyerapan protein dari bahan organik dapat meningkatkan kandungan protein Cacing Sutera.

Pada penelitian yang dilakukan Jaohari (2012), Cacing Sutera yang dipelihara menggunakan media kotoran sapi dan limbah lumpur kelapa sawit menghasilkan rata-rata pertambahan kandungan protein Cacing Sutera 5,37 \% pada hari ke 30 dan rata-rata pertambahan kandungan protein 2,89\% pada hari ke 60 .

\section{Kualitas Air}

Hasil pengukuran parameter kualitas air pada masing-masing media pemeliharaan cacing sutera (limnodrilus sp) pada setiap sampling dapat dilihat pada Tabel 6. 
Tabe1 6. Kisaran Parameter Kualitas Air Media Pemeliharaan Cacing Sutera pada Masing-masing Perlakuan

\begin{tabular}{lcccc}
\hline \multirow{2}{*}{ Perlakuan } & \multicolumn{3}{c}{ Parameter } \\
\cline { 2 - 5 } & Suhu $\left({ }^{\circ} \mathbf{C}\right)$ & $\mathbf{p H}$ & $\mathbf{D O}(\mathbf{m g} / \mathbf{L})$ & Amoniak $(\mathbf{m g} / \mathbf{L})$ \\
\hline $\mathrm{MK}_{0}$ & $25-28$ & $6,5-6,9$ & $4,90-6,48$ & $0,44-1,55$ \\
$\mathrm{MK}_{1}$ & $25-28$ & $6,2-7,0$ & $2,66-4,38$ & $1,19-2,820$ \\
$\mathrm{MK}_{2}$ & $25-28$ & $7,0-7,2$ & $3,81-5,78$ & $0,49-1,55$ \\
$\mathrm{MK}_{3}$ & $25-28$ & $5,8-6,5$ & $2,24-3,22$ & $0,88-2,32$ \\
\hline
\end{tabular}

Berdasarkan data kualitas air Tabel 6, kisaran nilai suhu, $\mathrm{pH}, \mathrm{DO}$ dan Amonia pada setiap perlakuan masih dalam batas kisaran optimal dan dapat mendukung kehidupan Cacing Sutera (Limnodrilus sp). Hal ini diduga kualitas air yang optimum menyebabkan metabolisme yang baik dan menyebabkan penyerapan gizi pada bahan organik lebih maksimal sehingga protein cacing Sutera meningkat sesuai dengan kandungan protein bahan organik. Marian dan Padian (1984), mengatakan kisaran optimal suhu dalam pertumbahan Cacing Sutera (Limnodrilus sp) $25-28{ }^{\circ} \mathrm{C}$. Hal ini juga dipertegas effendi (2013) bahwa kisaran suhu optimum untuk pertumbuhan cacing Sutera adalah $25-28^{\circ} \mathrm{C}$. Selanjutnya menurut Davis (1982) dalam Febrianti (2004),Cacing Sutera dapat beradaptasi pada $\mathrm{pH}$ berkisar 5,5-8,0.

Kisaran Oksigen terlarut (DO) yang optimum untuk pertumbuhan Cacing Sutera adalah 2,5-7 mg/1 (Efendi, 2013). Hal ini dinyatakan juga oleh Marian dan Pandian (1984) dalam Ansyari dan Rifa'I (2005) bahwa kebutuhan oksigen terlarut untuk cacing Sutera adalah 2,5-7. Selanjutnya, menurut Efendi (2013) kisaran ammonia yang optimum adalah < $3,6 \mathrm{mg} / \mathrm{L}$.

\section{KESIMPULAN DAN SARAN}

\section{Kesimpulan}

Kesimpulan yang didapat dari penelitian ini adalah kandungan protein pada bahan organik sebelum difermentasi dalam kotoran kambing sebesar 8,70 \%, Ampas tahu sebesar 6,90\%, Azolla pinnata sebesar 12,50 \% dan Ampas Kelapa sebesar 2,82\%. Selanjutnya, Kandungan protein pada bahan organik setelah difermentasi pada kotoran kambing sebesar 10,90\%, Ampas tahu sebesar 11,32 $\%$, Azolla pinnata sebesar 16,90\% dan Ampas Kelapa sebesar 6,10\%. Sedangkan, pertambahan nilai kandungan protein Cacing Sutera yang terbaik yaitu pada perlakuan $\mathrm{MK}_{2}=11,6 \%$.

\section{Saran}

Saran untuk penelitian perlu dilakukan penelitian lanjutan untuk mengetahui jenis bakteri yang terdapat pada cacing Sutera hasil kultur menggunakan media bahan organik yang berbeda.

\section{DAFTAR PUSTAKA}

Abdulkadir, S. 1989. Studies on Symbiotic Nitrogen Fixation by Azolla pinnata in Indonesia. PhD. Thesis. The University of Tokyo. Japan. (Unpublished)

Agustono, Widodo,S,A. dan Paramita,W. 2010. Kandungan Protein Kasar dan Serat Kasar pada Daun Kangkung Air (Ipomea aquatic) yang Difermentasi. Jurnal Ilmiah Perikanan dan Kelautan. 2 (1) : 37-43.

Ansyari, P. dan Rifa'i, A. M. 2005. Penggunaan Berbagai Dosis Pupuk Pelengkap Cair (PPC) Bioton untuk Pertumbuhan Populasi Cacing Sutera (Tubifex sp). Jurnal. Fakultas 
Perikanan. Universitas Lampung. Lampung.

Arifbowo, A, N,. 2007. Pengaruh Suplementasi Ampas Tahu, Ampas Tempe dan Ampas Kecap terhadap Kecernaan Bahan Kering dan Bahan Organik pada Domba Lokal Jantan. Skripsi. Fakultas Pertanian. Universitas Sebelas

Chumaidi, MS., Ilyas, S., Yunus, MS., Sahlan, M., Utami, r., Priyadi, A., Imanto, T.P., Hartati, T.S., Bastiawan, D., Jangkaru, Z., dan Arifudin, R. 1992. Pedoman Teknis Budidaya Pakan Alami Ikan dan Udang .Puslitbangkan

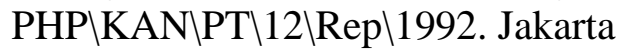

Effendi, M. 2013. Beternak Cacing Sutera Cara Modern. Penebar Swadaya. Jakarata

Febrianti, D. 2004. Pengaruh Pempukan Harian dengan Kotoran Ayam Terhadap Pertumbuhan Populasi dan Biomassa Cacing Sutera (Limndrillus). Skripsi. Fakultas Perikanan dan Ilmu Kelautan. Institut Pertanian Bogor. Bogor.

Hanafiah, K.A. 2005. Rancangan Percobaan. Raja Grafindo Persada. Jakarta.

Handajani. H. 2006. Peningkatan Nilai Nutrisi Tepung Azolla melalui Fermentasi. Naskah Publikasi. Fakultas Peternakan Perikanan. Universitas Muhammadyah Malang. Malang.

Hidayati, G, S. 2011. Pengolahan Ampas Kelapa dengan Mikroba Lokal sebagai Bahan Pakan Ternak Unggas Alternatif di Sumatera Barat. Jurnal Embrio. 4 (1) : 26-36.
Ismail, R. 2013. Peningkatan Pertumbuhan Populasi dan Biomassa Cacing Sutera (Limnodrilus sp) dengan Sistem Resirkulasi pada Model Wadah yang Berbeda. Skripsi. Fakultas Perikanan. Universitas PGRI Palembang. Palembang.

Jaohari, T. Y. 2012. Pemanfaatan Limbah Lumpur (Sludge) Kelapa Sawit dan Kotoran Sapi untuk Budidaya Cacing Sutera (Tubifex sp) dalam Pengembangan Pakan Alami Ikan. Tesis. Pascasarjana. Universitas Terbuka. Jakarta.

Mahfudz, D. L., Suprijatna, E., Sarengat, W. 2011. Ampas Tahu tingkatkan Produksi Broiler. Fakultas Peternakan. Universitas Diponegoro. Semarang.

Marian, M.,P. dan Pandian, T., J. 1984. Culture and Harvesting Techniques for Tubifex tubifex. Jurnal Aquakulture. Madurai Kamaraj University. Madurai. 42:303-315

Muchtadi. D. 2010. Teknik Evaluasi Nilai Gizi Protein. Alfabeta. Bandung.

Pursetyo, T.K., Satyantini, H.S., dan Mubarok, S.A. 2011. Pengaruh Pemupukan Ulang Kotoran Ayam Kering Terhadap Populasi Cacing Tubifex tubifex. Jurnal Ilmiah Perikanan dan Kelautan 3 (2) ; 177182.

Putri, F. M. 2010. Kandungan Gizi dan Sifat Fisik Tepung Ampas Kelapa Sebagai Bahan Pangan Sumber Serat. Jurnal Kompetensi Teknik. Fakultas Teknik. Universitas Negeri Semarang. 2 (2) : 32-43.

Rahman J,W. 2012. Efektifitas Penggunaan Berbagai Pupuk Kandang yang 
Difermentasi pada Budidaya Cacing Sutera Oligochaeta. Skripsi. Fakultas Perikanan dan Ilmu Kelautan. Institut Pertanian Bogor. Bogor.

Suharyadi. 2012. Studi Penumbuhan dan Produksi Cacing Sutra (Tubifex sp.) dengan Pupuk yang Berbeda dalam Sistem Resirkulasi. Tugas Akhir Tugas Magister Program Pasca Sarjana Universitas Terbuka. Jakarta.

Syam, S.F. 2012. Produktivitas Budidaya Cacing Sutera (Oligochaeta) dalam Resirkulasi Menggunakan Jenis Substrat dan Sumber Air yang
Berbeda. Skripsi. Fakultas Perikanan Dan Ilmu Kelautan. Institut Pertanian Bogor. Bogor.

Winarno. G,F. 1997.Kimia Pangan dan Gizi. Gramedia Pustaka Utama. Jakarta.

Winedar, H., Listyawati, S dan Sutarno. 2004. Daya Cerna Protein Pakan, Kandungan Protein Daging dan Pertambahan Berat Badan Ayam Broiler setelah Pemberian Pakan yang Difermentasi dengan EM-4. Jurnal Bioteknologi. 3 (1) : 14-19. 